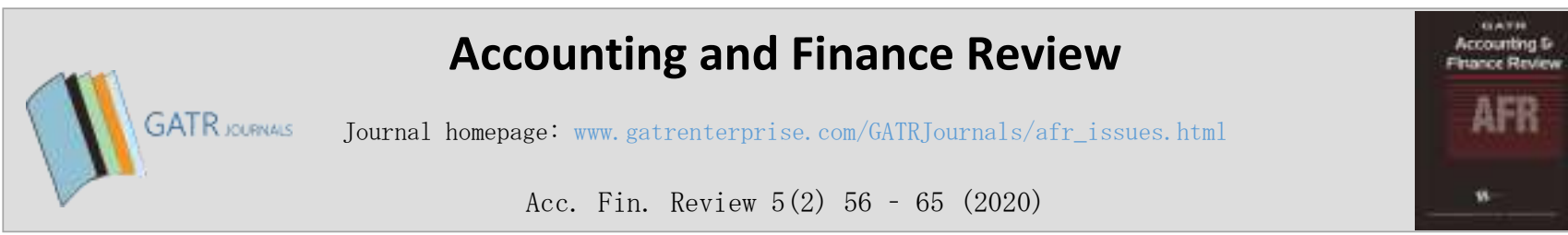

\title{
Are CEO Overconfidence and Audit Firm Size Related To Tax Avoidance?
}

\author{
Paulina Sutrisno $^{1} *$ and Kashan Pirzada ${ }^{2}$ \\ ${ }^{1}$ Trisakti School of Management, Jl. Kyai Tapa No. 20 Grogol, 11440, Jakarta, Indonesia \\ ${ }^{2}$ Asian Research Institute for Corporate Governance (ARICG) and Tunku Puteri Intan Safinaz School of Accountancy, \\ Universiti Utara Malaysia, Sintok, Malaysia
}

\begin{abstract}
Objective - This study aims to examine whether audit firm size mitigates the relationship between CEO overconfidence and tax avoidance. CEO overconfidence has the characteristics of a very high level of self-confidence which influences the pattern of thought and the way they make strategic decisions. CEO overconfidence has a tendency to avoid taxes. It aims to show competence in tax management and raise funds for investment. External party oversight, such as by audit firms, will mitigate the relationship between CEO overconfidence and tax avoidance through an attitude of independence, as well as competence and function as examiners of the company's financial reporting.

Methodology/Technique - This study uses a sample of Indonesian non-financial companies in the period 2013-2017. This study analyses the data with statistical methods using linear multiple regression.

Findings - The results of this study indicate that CEO overconfidence is positively related to tax avoidance, while audit firm size is negatively related to tax avoidance. However, this study has not been able to prove the influence of audit firm size on the relationship between CEO overconfidence and tax avoidance.

Type of Paper: Empirical

Keywords: CEO overconfidence; Tax Avoidance; Audit Firm Size; Big 4; Book Tax Difference.

Reference to this paper should be made as follows: Sutrisno, P; Pirzada, K. (2020). Are CEO Overconfidence and Audit Firm Size Related To Tax Avoidance?, Acc. Fin. Review, 5(2): 56 - 65. https://doi.org/10.35609/afr.2020.5.2(3)
\end{abstract}

JEL Classification: M41, M49.

\section{Introduction}

CEO overconfidence is one of the personal characteristics of leaders that influences corporate decision making (Bertrand \& Schoar, 2003; Habib \& Hossain, 2013; Hsieh et. al., 2018; Malmendier \& Tate, 2015). CEO overconfidence tends to overinvest, be innovative, risks taker, do a lot of research and development activities, take on debt to external parties, are reluctant to pay dividends, make earnings management and conduct fraud in financial reporting (Bharati et. al., 2016; Goel \& Thakor, 2008; Hirshleifer et. al., 2012; Hribar \& Yang, 2016; Malmandier \& Tate, 2008; Malmendier et. al., 2011; Schrand \& Zechman, 2012; Kouaib \& Jarboui, 2016). In addition, CEO overconfidence also tends to do tax avoidance (Chyz, 2013; Hsieh et. al., 2018). This is done to meet expected targets, improve reputation and personal credibility for their ability in tax planning (Lee, 2016; Presley \& Abbott, 2013) and raise funds for investment and innovation activities.

\footnotetext{
* Paper info: Revised: June 11, 2020

Accepted: September 30, 2020

* Corresponding author: Paulina Sutrisno

E-mail: paulina@stietrisakti.ac.id

Affiliation: Accounting Department, Trisakti School of Management, Indonesia
} 
Desai and Dharmapala (2009), Hanlon (2005) and Phillips et. al. (2003) show that tax avoidance is an effective way to achieve earnings targets and increase cash flow.

Too aggressive tax avoidance will cause damage to the company's reputation in the future (Hanlon, 2005), and may even cause a decline in stock prices (Hanlon \& Slemrod, 2009). Cook et. al. (2017) and Drake et. al. (2017) show that investors view tax avoidance as a potential loss in the future. For this reason, external auditors are needed to monitor corporate tax avoidance. Fan and Wong (2005) and Newman et. al. (2005) state that auditors as independent external parties have an important role in carrying out the supervisory function of the company to protect investors' rights over the fraudulent behavior of companies.

The size of a large audit firm is considered to have high audit quality because it strives to avoid litigation risk, reputation and regulation and strives to maintain credibility (DeFond \& Zhang, 2014; Guedhami et. al., 2014; Hope et. al., 2008). Big 4 audit firm is related to low levels of corporate fraud (DeFond \& Zhang, 2014). Likewise, Gaaya et. al. (2017) show that the existence of high audit quality (the audit firm size) reduces corporate tax avoidance. Kanagaretnam et. al. (2016) show that the Big 4 audit firm is related to low tax avoidance because those audit firms aim to maintain their reputation. Hanlon (2005) states that auditors will indirectly reduce corporate tax avoidance because the level of difference between earnings per book and per tax becomes a red-flag potential for tax authorities so that it will increase the likelihood of inspection. This causes audit firms that have corporate clients with high tax avoidance that will increase audit risk (Kanagaretnam et. al., 2016).

However, McGuire et. al. (2012) show that audit firms actually encourage tax avoidance when the audit firm is a tax expert because the audit firm can influence the company to carry out tax avoidance through tax advisory services. Likewise, Lisowsky (2010) shows that the size of audit firms is positively related to tax avoidance because auditors provide tax services. In contrast to Klassen et. al., (2016) it was found that companies audited by Big 4 audit firms who also provide tax services had lower levels of tax aggressiveness. The Big 4 audit firm seeks to maintain their reputation and avoid penalties from the authority.

Even though there are differences in the results of previous studies, this study predicts that external auditors can mitigate the relationship between CEO overconfidence and tax avoidance. This is supported by the argument that a large audit firm will maintain its reputation and credibility. This study examines nonfinancial companies in Indonesia for the period 2013-2017 with the exception of real estate and oil and gas companies that have final tax. Choi and Wong (2007) state that the size of an audit firm is one of the corporate governance mechanisms that is important when law enforcement practices and investor protection are weak. Indonesia is a country with weak law enforcement and investor protection practices (Claessens et. al., 2006). For this reason, the role of external parties such as audit firms in Indonesia will have a significant impact in limiting fraudulent actions committed by companies. The contribution of this study to the accounting literature is to show empirical evidence regarding the interaction between audit firms size and CEO overconfidence on tax avoidance. The implications of this study show that the size of an audit firm is a corporate governance component that is important in the context of Indonesia (which is a country with weak law enforcement and investor protection). In addition, this study provides a view of the policy of selecting audit firm size for a company.

\section{Literature Review}

\subsection{Tax Avoidance}

Lim (2011) defines tax avoidance as a form of tax savings by utilizing tax provisions that are carried out legally to minimize corporate tax obligations. Tax avoidance can be considered positive because it is an efficient form of tax planning, but aggressive tax avoidance is a form of tax fraud that has a negative impact on the company. Tax avoidance can be carried out in various ways such as: 
conducting income shifting or transfer pricing between affiliated companies or transferring income to foreign affiliated companies in tax haven countries or countries with lower tax rates;

The strategy of thin capitalization is the company's operational funding strategy which is dominated by debt to obtain tax deductions from the interest expense; and

Investments in intangible assets such as research and development expenditures which are tax deductible (Hsieh et. al., 2018; Richardson \& Taylor, 2015).

Hanlon and Heitzman (2010) state that tax avoidance has a number of specific benefits such as an increase in cash flow and shareholder welfare, however if tax avoidance is carried out excessively it will have consequences in the form of decreasing cash flow and shareholder welfare due to payment of penalties and damage to company reputation. Hanlon and Slemrod (2009) and Hanlon and Heitzmen (2010) states that firm value will increase due to tax avoidance, but there is a possibility that investors will react negatively to tax avoidance because they indicate the management of company self-interest to pursue profits and bonuses. Likewise, Armstrong et. al. (2015) states that tax avoidance is a risky decision for the company. Hanlon and Slemrod (2009) show that the market will react negatively to tax fraud.

\subsection{CEO Overconfidence and Tax Avoidance}

CEO overconfidence refers to a person with a high commitment to achieving certain targets and overestimating the abilities, competencies and knowledge they have to gain professional recognition and reputation (Hsieh et. al., 2018). CEO overconfidence also tends to take risks and not be careful in estimating investment returns (Heaton, 2002; Malmendier et. al., 2011; Presley \& Abbott, 2013). CEO overconfidence also has a tendency to raise external funds through debt (Ataullah et. al., 2018; Malmendier et. al., 2011) to fund investment and research and development activities (Kouaib \& Jarboui, 2016) which is one way to reduce taxes.

In addition, Hsieh et. al. (2018) state that CEO overconfidence is motivated to achieve high income levels to exceed the expected earnings targets as well as to raise funds for investment and business expansion so that CEO overconfidence is encouraged to carry out tax avoidance that could increase cash flow and exceed certain earnings targets. Frank and Rego (2009) identify an alignment between the aggressiveness of financial reporting and the aggressiveness of tax avoidance. CEO overconfidence also tends to do mergers and acquisitions even more towards international relations (Ferris et. al., 2013). This is one of CEO overconfidence strategies to carry out tax avoidance through income shifting or transfer pricing to countries with lower tax rates (Hsieh et. al., 2018). From the discussion above, it can be concluded that the characteristics of CEO overconfidence have a need to carry out tax avoidance that aim to collect certain funds to carry out investment activities through research and development expenditures or business expansion through mergers and acquisitions, in line with the tendency of corporate tax avoidance. Based on the description above, the first hypothesis of this study is:

H1 CEO over-confidence is positively related to tax avoidance.

\subsection{Relationship between Audit Firm Size, CEO Overconfidence and Tax Avoidance}

Audit firm size has the effect of overcoming agency conflicts that occur within a company because the size of a large audit firm will strive to maintain an international reputation and generally have a higher level of independence and quality assurance than smaller audit firms (Fan \& Wong, 2005). Likewise, research conducted DeFond and Zhang, (2014), Guedhami et. al. (2014) and Hope et. al. (2008) states that auditors from large audit firms (Big 4) have high audit quality due to high litigation risk and reputation. Audit firm size is a corporate governance mechanism that can protect investor rights and detect fraud committed by 
company management (Gaaya et. al., 2017; Newman et. al., 2005). This shows that the role of the external auditor in overseeing the management actions of the company is very important.

In the audit planning, the auditor will have an initial perception of the existence of CEO characteristics so that the company led by CEO overconfidence will encourage the auditor to conduct a wider scope of audits to reduce audit risk (Duellman et. al., 2015). DeFond and Zhang (2014) and Guan et. al. (2016) show that auditors are independent external parties in carrying out their duties to avoid audit risks such as litigation risk, reputation risk and regulatory risk. DeAngelo (1981) states that the size of a large audit firm shows a high level of independence and high audit quality. This is based on the idea that large-sized audit firms have big resources and competency levels so as to increase the possibility of detection of violations or fraud. Richardson et. al. (2013) states that the Big 4 audit firms can help reduce tax aggressive actions through increased monitoring and high audit quality.

However, McGuire et. al. (2012) shows that companies that request tax services from audit firms that simultaneously audit their financial statements show a high level of tax avoidance when the audit firm is a tax expert compared to an audit firm that is not a tax expert. This shows that it is possible that audit firms can facilitate company management to carry out tax avoidance because audit firms also offers non-assurance services, such as tax advice, which becomes an opportunity for company management to take action on tax aggressiveness to achieve its interests. In contrast, Klassen et. al. (2016) states that the Big 4 audit firms which simultaneously provides tax services will have a lower level of tax aggressiveness because they aim to avoid penalties. From the description above, it can be concluded that audit firm has an important role in overcoming corporate agency conflicts through the supervisory function carried out so as to reduce excessive tax avoidance. Gaaya et. al. (2017), Kanagaretnam et. al. (2016) and Richardson et. al. (2013) show that audit firm size has a role in overseeing corporate tax avoidance. Based on this, the research hypothesis can be expressed as follows:

H2 Audit firm size mitigates the relationship between CEO overconfidence and tax avoidance.

\section{Research Methodology}

\subsection{Sample and Research Data}

This study uses a sample of non-financial companies listed on the Indonesian Stock Exchange (IDX) in the period 2013-2017. This research issued several non-financial companies that have final tax rules such as real estate, oil and gas companies. The research period began in 2013 to avoid adjustments to financial reporting referring to IFRS because in Indonesia a convergence of financial reporting standards using IFRS was imposed in 2012, particularly for companies listed on the Indonesian Stock Exchange.

\subsection{Measurement of the Variables}

This study uses a Book-Tax Difference (BTD) measure to calculate the level of corporate tax avoidance. The higher the BTD, the greater likelihood of corporate tax avoidance. Wilson (2009) states that BTD is a powerful measure for calculating the level of corporate tax avoidance because BTD describes aspects of permanent differences and temporary differences in the magnitude of the company's tax burden. The BTD formula (Tang et. al., 2017) is described as follows:

$\mathrm{BTD}=($ Pretax Income $*$ Tax Rate-Income Tax $) /$ Total assets.

CEO overconfidence was measured using a combination of three proxies referred to in previous research (Kouaib \& Jarboui, 2016) which was adjusted to the appropriate context for Indonesia: 
Overinvestment calculated by reducing the residual regression of total asset growth and sales growth with the industry's residual median value for the year. Value 1 if the company residual is greater than the median residual industry, value 0 if the opposite;

Debt to equity ratio. Value 1 if the debt to equity ratio is greater than the median of the year industry, while the value of 0 if the opposite;

Dividend yield is dividend payment by the company. A value of 1 if the dividend yield is zero and the value of 0 if the opposite.

The measurement of CEO overconfidence is achieved by merging the three proxy values above. The CEO overconfidence score is 1 if two of the three CEO proxy overconfidences are 1 and 0 if the opposite (Kouaib \& Jarboui, 2016).

Audit firm size is measured by determining whether the company is audited by a Big 4 audit firm which is given a value 1 and value 0 if the company is audited by non-Big 4 firms. The Big 4 firms are considered to have higher independence and competence than non-Big 4 firms due to adequate auditor training activities and greater responsibility to maintain its reputation and credibility.

\section{Results}

Table 1 shows the results of the descriptive statistics of the dependent and independent variables in this study with a total observation of 1,458 per company-year.

Table 1. Descriptive Statistics

\begin{tabular}{ccccc}
\hline Variable & Mean & Std. Dev. & Min & Max \\
\hline BTD & -0.00504 & 0.02966 & -0.49626 & 0.161003 \\
OVERCONFIDENCE & 0.50245 & 0.50013 & 0 & 1 \\
AUDIT FIRM & 0.39027 & 0.48795 & 0 & 1 \\
MTB & 2.88361 & 23.8250 & -580.14 & 459.89 \\
PPE & 0.40571 & 0.24822 & 0.000051 & 0.964019 \\
LEV & 0.34848 & 0.57953 & 0.000009 & 12.65076 \\
ROA & 0.06620 & 0.12867 & -0.832139 & 0.730029 \\
OCF & 0.05895 & 0.11347 & -0.813670 & 0.808765 \\
NOI & 0.79739 & 0.40206 & 0 & 1 \\
SIZE & 21.3993 & 1.70632 & 15.2047 & 26.27574 \\
\hline
\end{tabular}

BTD is calculated using the pre-tax income formula multiplied by the tax rate (25\%) minus the income tax divided by total assets. OVERCONFIDENCE is a dummy variable combined with three proxy measurements (overinvestment, debt to equity, dividend yield). AUDIT FIRM is a dummy variable, value 1 if the company audited by a Big 4 firm, value 0 if the opposite. Control variables: MTB ratio with market capitalization formula divided by total book value. PPE is calculated by the formula plant, property, equipment divided by total assets. LEV is Debt to Equity Ratio. ROA is calculated by dividing earnings before interest and tax by total asset-1. OCF is calculated by the operating cash flow divided by total assets. NOI (Net Operating Income) is a dummy variable, a value of 1 for companies that record profits and a value of 0 if no profits are reported. SIZE is calculated by the natural logarithm of total assets.

Table 1 shows that BTD for the sample studied shows the magnitude of the difference between the average book-tax income is -0.00504 . The descriptive statistics show that, on average, half $(50.24 \%)$ of the nonfinancial companies listed on the IDX are led by CEO overconfidence. The average audit firm value shows that $39.03 \%$ of non-financial companies in Indonesia are audited by the Big 4 audit firms. The MTB (Market to Book) ratio is an average of 2.88. This shows that on average there is a growth in market capitalization 
value. The mean PPE is 40.57 which indicates that most components of the company's total assets are plant, property and equipment. A high PPE value indicates one aspect of a company's tendency to carry out tax avoidance activities. The average value of LEV (Debt to Total Assets) is 0.3484, which indicates that the company's debt component is only $34.84 \%$ of the total assets.

High LEV values indicate the tendency of companies to carry out tax avoidance activities through interest expense. The average value of ROA is $6.62 \%$ which shows the rate of return on the company's assets is positive. This shows the positive growth rate of the company. The average OCF value is 0.058 which indicates the amount of operating cash flow to the company's total assets of 5.8\%. The mean NOI (Net Operating Income) is 0.7974 which means that $79.74 \%$ of the non-financial companies listed on the IDX posted net operating profit. SIZE has an average value of 21.39 (logarithm of natural total assets).

Table 2. Results of Testing Research Hypotheses

\begin{tabular}{ccccc}
\hline & \multicolumn{2}{c}{ Model 1 } & \multicolumn{2}{c}{ Model 2} \\
& Coeff & p-value & Coeff & p-value \\
\hline OVERCONFIDENCE & $0.002155^{* *}$ & 0.019 & 0.0010289 & 0.396 \\
AUDIT FIRM & $-0.0036152^{*}$ & 0.075 & $-0.005161 * * *$ & 0.008 \\
OVERCONFIDENCE*AUDIT FIRM & & & 0.0028913 & 0.223 \\
MTB & 0.0000073 & 0.889 & 0.000008 & 0.874 \\
PPE & $0.0054331^{*}$ & 0.075 & $0.0055287 *$ & 0.071 \\
LEV & $-0.0142517^{* * *}$ & 0.0000 & $-0.0142987 * * *$ & 0.0000 \\
ROA & $0.1361065^{* * *}$ & 0.0000 & $0.1364431^{* * *}$ & 0.0000 \\
CFO & $-0.0441793^{* * *}$ & 0.0000 & $-0.044008 * * *$ & 0.0000 \\
NOI & 0.002789 & 0.205 & 0.0027271 & 0.215 \\
SIZE & 0.000811 & 0.124 & 0.0008234 & 0.115 \\
CONS & -0.0276649 & 0.008 & -0.027242 & 0.009 \\
Prob $>$ chi2 & & 0.0000 & & 0.0000 \\
R-squared & & 0.4101 & & 0.4117 \\
\hline$*) 10 \%, * *) 5 \%, * *) 1 \%$ & & & &
\end{tabular}

Table 2 shows the test results using the unbalance panel random effect regression analysis. The results of this study indicate the value of prob>chi2 is statistically significant which means that the research model is fit or feasible to use. The partial test results of each variable indicate that in model 1, CEO overconfidence is positively related to BTD with a significance value below 5\%. These results indicate that companies with CEO overconfidence tend to have high BTD levels which indicate tax avoidance. Hsieh et al. (2018) also shows that CEO overconfidence is more motivated to avoid tax evasion to improve its reputation by diverting tax payment funds for investment activities that will increase profits and increase CEO credibility in terms of efficiency in tax management. But the table also shows that for model 2, CEO overconfidence is not related to tax avoidance. This finding is quite reasonable because most CEOs do not have a tax background so that tax planning matters are left to the company's CFO (Dyreng et. al., 2010). The CEO also focuses more on the overall operational performance of the company rather than focusing solely on tax avoidance.

The results of this study indicate that audit firm is negatively related to corporate tax avoidance. This means that companies audited by the Big 4 audit firms have a lower level of tax avoidance compared to companies audited by non-Big 4 audit firms. Some reasons underlie this; first, companies audited by Big 4 firms are usually large companies so they are more careful in carrying out tax avoidance because they are subject to audit priorities by taxation bodies (Ayers et. al., 2015; Hoopes et. al., 2012). Large companies also try to maintain the company's reputation in the future so that they are less motivated to carry out high tax avoidance. Second, the Big 4 firms have the competence to monitor and detect corporate tax fraud and strive 
to maintain a number of risks that will arise due to high tax avoidance such as litigation risk and poor reputation (DeFond \& Zhang, 2014; Gaaya et. al., 2017; Kanagaretnam et. al., 2016).

The results of the interaction between CEO overconfidence and audit firm on tax avoidance in model two show insignificant results which means that the audit firm does not mitigate the relationship between CEO overconfidence and tax avoidance. This is because audit firms usually focus more on comprehensive financial reporting and entrust tax matters to independent tax consultants.

\section{Discussion}

This study examines the relationship between CEO overconfidence, audit firm size and tax avoidance. The findings of this study indicate that CEO overconfidence is positively related to corporate tax avoidance. This proves that CEO's personal characteristics are related to corporate tax avoidance (Dyreng et. al., 2010; Hsieh et. al., 2018). CEO overconfidence is motivated to carry out tax avoidance because it is more trying to raise funds for a number of investments and innovative projects. In addition, the CEO overconfidence seeks to show competence in tax efficiency as well as to enhance their reputation. This study also shows that audit firms size is negatively related to tax avoidance. Big 4 audit firms strive to maintain their reputation by not compromising on tax avoidance companies. However, audit firm size has no effect on the relationship between CEO overconfidence and tax avoidance because audit firms are more focused on corporate financial reporting while corporate taxation is the focus of the corporate tax consultant itself.

The regression test results in this study indicate that a number of control variables that are often used in previous research related to tax avoidance activities such as leverage (debt to total assets) and OCF (operating cash flow) have a negative relationship to tax avoidance activities. The higher the company's operating cash flow will be negatively related to the level of corporate tax avoidance. Meanwhile, the higher the company's leverage, the lower the tax avoidance activity will be. This is because companies with high leverage will be more careful because of supervision from third parties. PPE (Plant, Property \& Equipment) and ROA (Return on Assets) control variables show a positive relationship to tax avoidance activities. This shows that companies with a large company size and those that generate positive returns have a tendency to carry out tax avoidance activities. Ayers et. al. (2015) and Hoopes et. al. (2012) show that large companies tend to have high tax avoidance activities because they have a large amount of income that is taxable. While the MTB variable (Market to Books), NOI (Net Operating Income) and SIZE (company size) do not have an effect on tax avoidance.

\section{Conclusion}

This study shows that CEO overconfidence has a positive effect on tax avoidance. Thus, companies led by CEO overconfidence have a tendency to avoid high taxes because CEO overconfidence can benefit from the low taxes paid to invest in innovative projects that are able to increase their ability to the public. This study also confirms that audit firm size is one of the mechanisms of good corporate governance that is able to mitigate tax avoidance by companies. However, audit firm size does not affect the relationship between CEO overconfidence and tax avoidance. That is because audit firm is not focused on corporate tax avoidance but rather on the firm's financial reporting itself because corporate taxes are usually handled directly by corporate tax consultants.

The findings of this study are similar to those of previous studies (Dyreng et. al., 2010; Hsieh et. al., 2018), which conclude that the CEO's personal characteristics have a positive relationship to tax avoidance. This can be an understanding of the tax authorities regarding the relationship between the CEO's personal characteristics, namely overconfidence, and tax avoidance. Likewise, audit firm size can also reduce corporate tax avoidance.

The limitations of this study are related to the measurement of CEO overconfidence which only measures from a quantitative perspective. Further research can add a measure of overconfidence from a qualitative 
perspective such as using media to be able to measure overconfidence more comprehensively. Further research can also test $\mathrm{CFO}$ overconfidence on tax avoidance because corporate tax planning is primarily the responsibility of the CFO.

\section{References}

Armstrong, C. S., Blouin, J. L., Jagolinzer, A. D., \& Larcker, D. F. (2015). Corporate governance, incentives, and tax avoidance. Journal of Accounting and Economics, 60(1), 1-17. https://doi.org/10.1016/j.jacceco.2015.02.003

Ataullah, A., Vivian, A., \& Xu, B. (2018). Time-varying managerial overconfidence and corporate debt maturity structure. The European Journal of Finance, 24(2), 157-181. https://doi.org/10.1080/1351847X.2016.1274266

Ayers, B. C., Seidman, J. K., \& Towery, E. (2017). Taxpayer behavior under audit certainty. Available at SSRN 2609134. https://papers.ssrn.com/sol3/papers.cfm?abstract_id=2609134

Bertrand, M., \& Schoar, A. (2003). Managing with style: The effect of managers on firm policies. The Quarterly journal of economics, 118(4), 1169-1208. https://doi.org/10.1162/003355303322552775

Bharati, R., Doellman, T., \& Fu, X. (2016). CEO confidence and stock returns. Journal of Contemporary Accounting \& Economics, 12(1), 89-110. https://doi.org/10.1016/j.jcae.2016.02.006

Choi, J. H., \& Wong, T. J. (2007). Auditors' governance functions and legal environments: An international investigation. Contemporary accounting research, 24(1), 13-46. https://doi.org/10.1506/X478-1075-4PW5-1501

Chyz, J. A. (2013). Personally tax aggressive executives and corporate tax sheltering. Journal of Accounting and Economics, 56(2-3), 311-328. https://doi.org/10.1016/j.jacceco.2013.09.003

Claessens, S., Fan, J. P., \& Lang, L. H. (2006). The benefits and costs of group affiliation: Evidence from East Asia. Emerging Markets Review, 7(1), 1-26. https://doi.org/10.1016/j.ememar.2005.08.001

Cook, K. A., Moser, W. J., \& Omer, T. C. (2017). Tax avoidance and ex ante cost of capital. Journal of Business Finance \& Accounting, 44(7-8), 1109-1136. https://doi.org/10.1111/jbfa.12258

DeAngelo, L. E. (1981). Auditor size and audit quality. Journal of accounting and economics, 3(3), 183-199.

DeFond, M., \& Zhang, J. (2014). A review of archival auditing research. Journal of accounting and economics, 58(2-3), 275-326. https://doi.org/10.1016/j.jacceco.2014.09.002

Desai, M. A., \& Dharmapala, D. (2009). Corporate tax avoidance and firm value. The review of Economics and Statistics, 91(3), 537-546. https://www.mitpressjournals.org/doi/abs/10.1162/rest.91.3.537

Drake, K. D., Lusch, S. J., \& Stekelberg, J. (2019). Does tax risk affect investor valuation of tax avoidance? Journal of Accounting, Auditing \& Finance, 34(1), 151-176. https://journals.sagepub.com/doi/full/10.1177/0148558X17692674

Duellman, S., Hurwitz, H., \& Sun, Y. (2015). Managerial overconfidence and audit fees. Journal of Contemporary Accounting \& Economics, 11(2), 148-165. https://doi.org/10.1016/j.jcae.2015.05.001

Dyreng, S. D., Hanlon, M., \& Maydew, E. L. (2010). The effects of executives on corporate tax avoidance. The accounting review, 85(4), 1163-1189. https://doi.org/10.2308/accr.2010.85.4.1163

Fan, J. P., \& Wong, T. J. (2005). Do external auditors perform a corporate governance role in emerging markets? Evidence from East Asia. Journal of accounting research, 43(1), 35-72. https://doi.org/10.1111/j.1475679x.2004.00162.x

Ferris, S. P., Jayaraman, N., \& Sabherwal, S. (2013). CEO overconfidence and international merger and acquisition activity. Journal of Financial and Quantitative Analysis, 137-164. https://www.jstor.org/stable/43303795

Frank, M. M., Lynch, L. J., \& Rego, S. O. (2009). Tax reporting aggressiveness and its relation to aggressive financial reporting. The Accounting Review, 84(2), 467-496. https://doi.org/10.2308/accr.2009.84.2.467

Gaaya, S., Lakhal, N., \& Lakhal, F. (2017). Does family ownership reduce corporate tax avoidance? The moderating effect of audit quality. Managerial Auditing Journal. https://doi.org/10.1108/MAJ-02-2017-1530

Thakor, A. V., \& Goel, A. M. Overconfidence, CEO Selection, and Corporate Governance. Journal of Finance, Forthcoming. https://papers.ssrn.com/sol3/papers.cfm?abstract_id=1008513

Guan, Y., Su, L. N., Wu, D., \& Yang, Z. (2016). Do school ties between auditors and client executives influence audit outcomes? Journal of accounting and economics, 61(2-3), 506-525. https://doi.org/10.1016/j.jacceco.2015.09.003

Guedhami, O., Pittman, J. A., \& Saffar, W. (2014). Auditor choice in politically connected firms. Journal of Accounting Research, 52(1), 107-162. https://doi.org/10.1111/1475-679X.12032

Habib, A., \& Hossain, M. (2013). CEO/CFO characteristics and financial reporting quality: A review. Research in Accounting Regulation, 25(1), 88-100. https://doi.org/10.1016/j.racreg.2012.11.002 
Hanlon, M. (2005). The persistence and pricing of earnings, accruals, and cash flows when firms have large book-tax differences. The accounting review, 80(1), 137-166. https://meridian.allenpress.com/accounting-review/articleabstract/80/1/137/53500

Hanlon, M., \& Heitzman, S. (2010). A review of tax research. Journal of accounting and Economics, 50(2-3), 127-178. https://doi.org/10.1016/j.jacceco.2010.09.002

Hanlon, M., \& Slemrod, J. (2009). What does tax aggressiveness signal? Evidence from stock price reactions to news about tax shelter involvement. Journal of Public Economics, 93(1-2), 126-141. https://doi.org/10.1016/j.jpubeco.2008.09.004

Heaton, J. B. (2002). Managerial optimism and corporate finance. Financial management, 33-45. https://www.jstor.org/stable/3666221

Hirshleifer, D., Low, A., \& Teoh, S. H. (2012). Are overconfident CEOs better innovators?. The journal of finance, 67(4), 1457-1498. https://doi.org/10.1111/j.1540-6261.2012.01753.x

Hoopes, J. L., Mescall, D., \& Pittman, J. A. (2012). Do IRS audits deter corporate tax avoidance?. The accounting review, 87(5), 1603-1639. https://doi.org/10.2308/accr-50187

Hope, O. K., Kang, T., Thomas, W., \& Yoo, Y. K. (2008). Culture and auditor choice: A test of the secrecy hypothesis. Journal of Accounting and Public Policy, 27(5), 357-373. https://doi.org/10.1016/j.jaccpubpol.2008.07.003

Hribar, P., \& Yang, H. (2016). CEO overconfidence and management forecasting. Contemporary accounting research, 33(1), 204-227. https://doi.org/10.1111/1911-3846.12144

Hsieh, T. S., Wang, Z., \& Demirkan, S. (2018). Overconfidence and tax avoidance: The role of CEO and CFO interaction. Journal of Accounting and Public Policy, 37(3), 241-253. https://doi.org/10.1016/j.jaccpubpol.2018.04.004

Kanagaretnam, K., Lee, J., Lim, C. Y., \& Lobo, G. J. (2016). Relation between auditor quality and tax aggressiveness: Implications of cross-country institutional differences. Auditing: A Journal of Practice \& Theory, 35(4), 105-135. https://doi.org/10.2308/ajpt-51417

Klassen, K. J., Lisowsky, P., \& Mescall, D. (2016). The role of auditors, non-auditors, and internal tax departments in corporate tax aggressiveness. The Accounting Review, 91(1), 179-205. https://meridian.allenpress.com/accountingreview/article-abstract/91/1/179/53570

Kouaib, A., \& Jarboui, A. (2016). The moderating effect of CEO profile on the link between cutting R\&D expenditures and targeting to meet/beat earnings benchmarks. The Journal of High Technology Management Research, 27(2), 140160. https://doi.org/10.1016/j.hitech.2016.10.005

Lee, J. E. (2016). CEO overconfidence and the effectiveness of internal control over financial reporting. Journal of Applied Business Research (JABR), 32(1), 81-100. https://clutejournals.com/index.php/JABR/article/view/9525

Lim, Y. (2011). Tax avoidance, cost of debt and shareholder activism: Evidence from Korea. Journal of Banking \& Finance, 35(2), 456-470. https://doi.org/10.1016/j.jbankfin.2010.08.021

Lisowsky, P. (2010). Seeking shelter: Empirically modeling tax shelters using financial statement information. The Accounting Review, 85(5), 1693-1720. https://doi.org/10.2308/accr.2010.85.5.1693

Malmendier, U., \& Tate, G. (2008). Who makes acquisitions? CEO overconfidence and the market's reaction. Journal of financial Economics, 89(1), 20-43. https://doi.org/10.1016/j.jfineco.2007.07.002

Malmendier, U., \& Tate, G. (2015). Behavioral CEOs: The role of managerial overconfidence. Journal of Economic Perspectives, 29(4), 37-60. DOI: 10.1257/jep.29.4.37

Malmendier, U., Tate, G., \& Yan, J. (2011). Overconfidence and early-life experiences: the effect of managerial traits on corporate financial policies. The Journal of finance, 66(5), 1687-1733. https://doi.org/10.1111/j.15406261.2011.01685.x

McGuire, S. T., Omer, T. C., \& Wang, D. (2012). Tax avoidance: Does tax-specific industry expertise make a difference?. The Accounting Review, 87(3), 975-1003. https://doi.org/10.2308/accr-10215

Newman, D. P., Patterson, E. R., \& Smith, J. R. (2005). The role of auditing in investor protection. The Accounting Review, 80(1), 289-313. https://doi.org/10.2308/accr.2005.80.1.289

Phillips, J., Pincus, M., \& Rego, S. O. (2003). Earnings management: New evidence based on deferred tax expense. The accounting review, 78(2), 491-521. https://meridian.allenpress.com/accounting-review/article-abstract/78/2/491/53281

Presley, T. J., \& Abbott, L. J. (2013). AIA submission: CEO overconfidence and the incidence of financial restatement. Advances in Accounting, 29(1), 74-84. https://doi.org/10.1016/j.adiac.2013.03.007

Richardson, G., \& Taylor, G. (2015). Income shifting incentives and tax haven utilization: Evidence from multinational US firms. The International Journal of Accounting, 50(4), 458-485. https://doi.org/10.1016/j.intacc.2015.10.001 
Richardson, G., Taylor, G., \& Lanis, R. (2013). The impact of board of director oversight characteristics on corporate tax aggressiveness: An empirical analysis. Journal of Accounting and Public Policy, 32(3), 68-88. https://doi.org/10.1016/j.jaccpubpol.2013.02.004

Schrand, C. M., \& Zechman, S. L. (2012). Executive overconfidence and the slippery slope to financial misreporting. Journal of Accounting and economics, 53(1-2), 311-329. https://doi.org/10.1016/j.jacceco.2011.09.001

Tang, T., Mo, P. L. L., \& Chan, K. H. (2017). Tax collector or tax avoider? An investigation of intergovernmental agency conflicts. The Accounting Review, 92(2), 247-270. https://doi.org/10.2308/accr-51526

Wilson, R. J. (2009). An examination of corporate tax shelter participants. The Accounting Review, 84(3), 969-999. https://doi.org/10.2308/accr.2009.84.3.969 